\title{
Utilization Pattern of Mobile Phone among Registered Women Vendors in Imphal Ema Market of Manipur, India
}

\author{
Chungkham Narendrajit Singh*, Daya Ram and Rebani Akoijam
}

College of Agriculture, Central Agricultural University, Imphal-795004 (Manipur), India

*Correspondence author

\begin{abstract}
A B S T R A C T
Keywords

Mobile phone,

Utilization,

Registered women

vendors

Article Info

Accepted:

17 June 2018

Available Online:

10 July 2018

Mobile phones provide real time services that reduce costs, increase income, increases reach ability and mobility. They also facilitate the extension of social and business networks that empower women with knowledge to gain emancipation. The present study was carried out in Ema market of Imphal West district to study the utilization pattern of mobile phone among registered women vendors. A sample of 120 registered women vendors were selected from Ema market by taking 56, 40 and 24 registered women vendors through proportionate random sampling from market segments namely Purana bazaar, New market and Laxmi bazaar respectively. Majority (93.33\%) of the women own feature phone, majorly used service providers by the women were Service provider-2 $(52.5 \%)$ and Service provider-1 $(48.33 \%)$, all respondents agreed that cellular mobile service to them was useful, all the respondents use only pre-paid mode of payment, Service provider- 2 is the most preferred choice of mobile service provider and difficulty in using various mobile apps in smart phone is found to be the major constraint.
\end{abstract}

\section{Introduction}

The mobile phone is emerging as a powerful tool and the usage of mobile phones have dramatically expanded since the 1990s (UCC, 2010). Mobile phones provide real time services that reduce costs, increase income, increases reach ability and mobility. They also facilitate the extension of social and business networks that empower women with knowledge to gain emancipation. In addition, mobile phones clearly substitute for journeys, brokers, trades and other business intermediaries (Donner and Escobari, 2010). Mobile phone ownership gives women the ability to open a mobile phone-based bank account, an important gateway to financial independence. A private account gives women in developing nations control over their money as well as the ability to put food on the family table. A mobile phone also gives women the ability to open a business in a remote village, without having to trek to a distant city to register that business. And, with a phone, women in developing countries can more easily schedule a clinic appointment or register their children for school. But these benefits are unavailable to the 1.7 billion women in developing countries who don't own a mobile phone. Around the world, women are 
14 percent less likely than men to own a mobile phone, according to the GSMA, an association representing mobile operators worldwide. The situation is even worse in South Asia, where women on average are 38.00 percent less likely to own a mobile phone than men (Klapper, 2016)

Ema market is considered the largest women's market in Asia, in the heart of Imphal town, Manipur. It is also known as Ema keithel or Khwairamb and Bazar; a place where equality is preached and practiced. Ema means mother and keithel means market. So, it is known as mother's market. Any women regardless of her background, community or religion can set a store here by registering in Imphal Municipal Cooperation. Registered women vendors; women who registered their name in Imphal Municipal Cooperation and hold vendor card. Vendor card is a license to the shed and to open their vendor under roof of Ema Market.

This research is inspired by the rapid increase in adoption and usage of mobile phones in developing countries. However, despite widespread adoption and usage of innovative mobile phone services, it is still not well understood whether mobile phones are used for business particularly by women.

\section{Materials and Methods}

The present study was conducted in Imphal (Imphal West) Ema Market of Manipur. Ema market consist of three market segments namely Purana bazaar, New market and Laxmi bazaar which have total registered women vendors of 1691, 1195 and 728 respectively. So, total of 3614 registered women vendors are in Ema market. A sample of 120 registered women vendors were selected from Ema market by taking 56, 40 and 24 registered women vendors through proportionate random sampling from market segments namely Purana bazaar, New market and Laxmi bazaar respectively. Data was collected with the help of pre tested schedule. The data collected from the respondents were scored, tabulated and analyzed using suitable statistical tools i.e., frequencies and percentages.

\section{Results and Discussion}

\section{Type of mobile phone}

Majority (93.33\%) of the respondents own feature phones and only $(6.67 \%)$ of the respondents use smart phones because feature phones are available in the most affordable prices compare to smart phones. More than half $(58.33 \%)$ of the respondents had single SIM and 41.67 per cent of the respondent had dual SIM type. The companies of the phone were Samsung (40.83\%), Nokia $(37.5 \%)$ and others $(21.67 \%)$. Majorly, they were using Samsung due to famous company name and users confidence (Komunte, 2015).

\section{Service provider}

Majorly used service providers by the women were Service provider-2 (52.5\%) and Service provider-1 (48.33\%) as they are more preferred by the respondents because they provide good quality service. More than half $(55.83 \%)$ of the respondent was use only one service provider without changing. However, 44.17 per cent had change to other service providers with one $(36.67 \%)$, two $(8.33 \%)$ and more than two $(1.66 \%)$ in the past. This trend may be due to loss of mobile phone or network connectivity problem. The service provider they used in the past were Service provider-4 (20.83\%), Service provider-1 $(11.66 \%)$, Service provider-2 (10\%), Service provider-5 $(8.33 \%)$ and Service provider-3 $(5 \%)$. The factors considered while choosing the service provider were majorly the network coverage by the respondents followed by the quality service $(55 \%)$ and fair pricing $(43.33 \%)$. 
Table.1 Distribution of respondents based on utilization pattern of mobile phone among registered women vendors $(n=120)$

\begin{tabular}{|c|c|c|c|c|}
\hline Sl. No. & Item & Classification & f & $\%$ \\
\hline I & \multicolumn{4}{|l|}{ Type of the mobile phone } \\
\hline \multirow[t]{2}{*}{1.} & \multirow[t]{2}{*}{ Type of phone } & Smartphone & 8 & 6.67 \\
\hline & & Feature phone & 112 & 93.33 \\
\hline \multirow[t]{2}{*}{2.} & \multirow[t]{2}{*}{ Number of SIM } & Single SIM & 70 & 58.33 \\
\hline & & Dual SIM & 50 & 41.67 \\
\hline \multirow[t]{3}{*}{3.} & \multirow[t]{3}{*}{ Company } & Samsung & 49 & 40.83 \\
\hline & & Nokia & 45 & 37.5 \\
\hline & & Others & 26 & 21.67 \\
\hline II & Service provider & & & \\
\hline \multirow[t]{6}{*}{1.} & \multirow[t]{6}{*}{ Current cellular service provider } & Service provider-1 & 58 & 48.33 \\
\hline & & Service provider-2 & 63 & 52.5 \\
\hline & & Service provider-3 & 16 & 13.33 \\
\hline & & Service provider-4 & 0 & 0 \\
\hline & & Service Provider-5 & 6 & 5 \\
\hline & & Service provider-6 & 0 & 0 \\
\hline \multirow[t]{2}{*}{2.} & \multirow{2}{*}{ First service provider } & Yes & 67 & 55.83 \\
\hline & & No & 53 & 44.17 \\
\hline \multirow[t]{3}{*}{3.} & \multirow[t]{3}{*}{ Service providers used in the past } & One & 44 & 36.67 \\
\hline & & Two & 10 & 8.33 \\
\hline & & More than two & 2 & 1.66 \\
\hline \multirow[t]{6}{*}{4.} & \multirow[t]{6}{*}{ Service provider availed in the past } & Service provider-1 & 14 & 11.66 \\
\hline & & Service provider-2 & 12 & 10 \\
\hline & & Service provider-3 & 6 & 5 \\
\hline & & Service provider-4 & 25 & 20.83 \\
\hline & & Service Provider-5 & 0 & 0 \\
\hline & & Service provider-6 & 10 & 8.33 \\
\hline \multirow[t]{4}{*}{5.} & \multirow{4}{*}{$\begin{array}{l}\text { Factors consider while choosing } \\
\text { cellular services }\end{array}$} & Network Coverage & 120 & 100 \\
\hline & & Fair Pricing & 52 & 43.33 \\
\hline & & Quality Service & 66 & 55 \\
\hline & & Attractive Packages & 0 & 0 \\
\hline III & Usage of the mobile phones & & & \\
\hline \multirow[t]{4}{*}{1.} & \multirow[t]{4}{*}{ Cellular mobile service to you } & Useful & 120 & 100 \\
\hline & & Essential & 67 & 55.83 \\
\hline & & Personal & 81 & 67.5 \\
\hline & & Status Symbol & 0 & 0 \\
\hline \multirow[t]{2}{*}{2.} & \multirow[t]{2}{*}{ Purpose of using mobile mostly } & Home (personal) & 120 & 100 \\
\hline & & Business & 91 & 75.83 \\
\hline 3. & Basic use of mobiles & SMS & 0 & 0 \\
\hline
\end{tabular}




\begin{tabular}{|c|c|c|c|c|}
\hline & & Voice calls & 120 & 100 \\
\hline \multirow[t]{6}{*}{4.} & \multirow{6}{*}{ Types of mobile apps mostly used } & Web browser & 0 & 0 \\
\hline & & Online apps & 0 & 0 \\
\hline & & Radio & 11 & 9.16 \\
\hline & & Camera & 14 & 11.67 \\
\hline & & Calculator & 13 & 10.83 \\
\hline & & Others & 11 & 9.16 \\
\hline IV & \multicolumn{4}{|l|}{ Payment details } \\
\hline \multirow[t]{2}{*}{1.} & \multirow[t]{2}{*}{ Mode of payment } & Pre-paid & 120 & 100 \\
\hline & & Post-paid & 0 & 0 \\
\hline \multirow[t]{4}{*}{2.} & \multirow{4}{*}{$\begin{array}{l}\text { Average amount spent on mobile usage } \\
\text { per month }\end{array}$} & Less than Rs. 100 & 10 & 8.33 \\
\hline & & Rs. $100-200$ & 53 & 44.17 \\
\hline & & Rs. $200-300$ & 48 & 40 \\
\hline & & More than Rs. 300 & 9 & 7.5 \\
\hline
\end{tabular}

Table.2 Distribution of respondents based on preferential choice of mobile service provider

\begin{tabular}{|l|l|c|c|c|}
\hline Sl. No. & Service provider & f & $\%$ & Rank \\
\hline 1. & Service provider-1 & 52 & 43.33 & II \\
\hline 2. & Service provider-2 & 56 & 46.67 & I \\
\hline 3. & Service provider-3 & 10 & 8.33 & III \\
\hline 4. & Service Provider-5 & 2 & 1.67 & IV \\
\hline
\end{tabular}

It was found that Service provider-2 was the most preferred choice of mobile service provider followed by Service provider-1, Service provider-3 and SERVICE PROVIDER-5.

Table.3 Constraints perceived by the women

\begin{tabular}{|l|l|c|c|c|}
\hline Sl. No. & Particulars & f & $\%$ & Rank \\
\hline 1. & Fluctuation in mobile network service & 43 & 35.8 & IV \\
\hline 2. & Difficulty in using various mobile apps in smart phone & 84 & 70 & I \\
\hline 3. & High price in mobile SIM recharge & 31 & 25.83 & VI \\
\hline 4. & Low visibility because of small screen & 28 & 23.33 & VII \\
\hline $\mathbf{5 .}$ & Inadequate demonstration of new technologies & 68 & 56.6 & III \\
\hline 6. & Lack of finance to buy new phone & 36 & 32 & V \\
\hline 7. & Lack of awareness about beneficiary of mobile internet service & 80 & 66.67 & II \\
\hline
\end{tabular}

\section{Usage of the mobile phone}

All respondents agreed that cellular mobile service to them was useful while more than half $(55.83 \%)$ of the respondent had found it to be essential and personal (67.5\%). These indicated that mobile phone was truly integrated in the lives of the women of Ema market and use in all aspects of their lives. The mobile phones were used for various purposes like home by all the respondents and business $(75.83 \%)$. Thus, the mobile phones are used for communicating with family, friends, relatives and for business purposes. All the respondents had found that the basic use of mobile phone as voice call only. It is 
found that 11.67 percent of the respondent used mobile camera app followed by $(10.83 \%)$ calculator, $(9.16 \%)$ radio, others (like games, music player) 9.16 per cent and no respondents were found to be using web browser and online apps in mobile phone. (Komunte et al., 2012) and (Blumenstock and Eagle 2010)

\section{Payment details}

All the respondents use only pre-paid mode of payment as it is the most affordable way for them as they can monitor their usages per their budget.

On monthly basis, majority $(44.17 \%)$ of the respondent were found to spent about an average amount of Rs. 100 to 200 followed by (40\%) Rs.200 to 300, (8.33\%) less than Rs. 100 and 7.5 per cent of the respondent spent more than Rs. 300 on mobile phone.

Difficulty in using various mobile apps in smart phone is found to be the major constraint followed by lack of awareness about beneficiary of mobile internet service, inadequate demonstration of new technologies, fluctuation in mobile network service, lack of finance to buy new phone, high price in mobile SIM recharge and low visibility because of small screen.

It can be concluded that majority $(93.33 \%)$ of the women own feature phone, majorly used service providers by the women were Service provider-2 (52.5\%) and Service provider-1 $(48.33 \%)$, all respondents agreed that cellular mobile service to them was useful, all the respondents use only pre-paid mode of payment, Service provider-2 is the most preferred choice of mobile service provider and difficulty in using various mobile apps in smart phone is found to be the major constraint.

\section{Acknowledgement}

The authors acknowledge the contribution of Ch. Narendrajit Singh, Daya Ram, M.K. Singh and Rebani Akoijam of College of Agriculture, Central Agricultural University, Imphal, Manipur (India) for the technical support and valuable contribution to the manuscript.

\section{References}

Blumenstock, J. and Eagle, N. (2010). Mobile Divides: Gender, Socioeconomic Status, and Mobile phone Use in Rwanda available at http:// www.jblumenstock.com/files/papers/jbl umenstock_ictd2010.pdf

Bordoloi, P. (2015). A Stroll in Ema Market. Eclectic Northeast.

Consolata Mutisya, Dr. Wambui Kiai and Dr. Ndeti Ndati (2016). Extent of Adoption And Usage of Mobile Phone Services in Empowering Women Entrepreneurs in Machakos County, Kenya. IOSR Journal Of Humanities And Social Science. 21(7): 48-59

Donner Jonathan and Escobari Marcela (2010). A review of the Research on Mobile Phone use by Micro and Small Enterprises, ICTD2009.

Klapper, L. (2016). How mobile phones are changing women's lives. World Economic Forum. Available via https://www.weforum.org/agenda/2016/ 04/how-mobile-phones-are-changingwomens-lives?platform=hootsuite. Accessed 04 Apr 2016

Komunte, M., A. S. Rwashana and J. Nabukenya. (2012). Comparative Analysis of Mobile Phone Usage among Women Entrepreneurs in Uganda and Kenya. African Journal of Computing \& ICT. 5(5): 74-86

Komunte, M., (2015). Usage of Mobile Technology in Women Entrepreneurs: 
A case Study of Uganda. The African Journal of Information Systems, 2015 July; 7(3): 60-61

Sarin, A. and Jain,R. (2009). Effects of mobiles on socio-economic life of urban poor. Research and publications,
Indian Institute of Management, Ahmedabad, pp. 13-20.

UCC (2010). Status of the communication market, Market review. Available at: http://www.ucc.co.ug. Retrieved on: 20. 8. 2011.

\section{How to cite this article:}

Chungkham Narendrajit Singh, Daya Ram and Rebani Akoijam, 2018. Utilization Pattern of Mobile Phone among Registered Women Vendors in Imphal Ema Market of Manipur, India. Int.J.Curr.Microbiol.App.Sci. 7(07): 2388-2393. doi: https://doi.org/10.20546/ijcmas.2018.707.278 